\title{
ANALISIS PRODUK SANTAN UNTUK PENGEMBANGAN STANDAR NASIONAL PRODUK SANTAN INDONESIA
}

\author{
Analysis of Coconut Milk Products for Development of The National Standard of \\ Indonesian Coconut Milk Products
}

\author{
Santi Ariningsih, Reno Fitri Hasrini dan Ainun Khoiriyah \\ Balai Besar Industri Agro (BBIA), Kementerian Perindustrian \\ Jl. Ir. H. Juanda No. 11, Bogor 16122 \\ E-mail: santi.ariningsih@yahoo.com
}

\begin{abstract}
Abstrak
Perkembangan teknologi yang semakin pesat menyebabkan masyarakat mencari suatu bahan yang bersifat praktis salah satunya yaitu pembuatan santan dalam bentuk siap pakai. Saat ini santan instan sudah banyak beredar di pasaran di Indonesia, namun standar nasional yang ada belum mengatur diversifikasi produk santan tersebut. Tujuan dari penelitian ini adalah untuk mengetahui karakteristik produk santan yang beredar di pasar dan menetapkan konsep RSNI Produk santan. Metode penelitian yang digunakan dalam penelitian ini adalah dengan mengkaji hasil analisis parameter mutu produk santan serta membandingkannya dengan SNI 01-3816-1995 santan cair dan codex stan 2402003. Parameter mutu yang dianalisis adalah $\mathrm{pH}$, kadar air, padatan total, lemak dan asam lemak bebas Hasil analisis terhadap santan encer, santan, santan krim, santan konsentrat dan santan bubuk mempunyai kisaran nilai pH sebesar 4,70 - 5,51, kadar air santan bubuk 2,41\%, padatan total sebesar 14,07 - 36,88\%, lemak sebesar 10,50 - 37,03\%, asam lemak bebas 0,21 - 0,37\%. Konsep RSNI Produk Santan yang diusulkan berdasarkan hasil analisis parameter mutu produk santan dan dibandingkan dengan SNI 01-3816-1995 santan cair dan codex stan 240-2003 adalah pH min. 5,9, kadar air maks. $5 \%$ hanya dipersyaratkan untuk santan bubuk, padatan total untuk santan encer, santan, santan krim dan santan konsentrat sebesar 6,6-12,6\%; 12,7-25,3\%; 25,4-37,3\%; min. 37,4\%, untuk santan bubuk tidak ditetapkan, lemak untuk santan encer, santan, santan krim, santan konsentrat dan santan bubuk berturut-turut sebesar $5,0 \% ; 10,0 \% ; 20,0 \% ; 29,0 \%$; dan min. 30\%. Asam lemak bebas untuk santan encer, santan, santan krim dan santan konsentrat maks. 0,3\%, dan maks. 0,2\% untuk santan bubuk.
\end{abstract}

Kata kunci: santan encer, santan, santan krim, santan konsentrat, santan bubuk

\begin{abstract}
Technological developments have led people to look for materials that are practical, one of which is making coconut milk in a ready-to-use. Currently instant coconut milk has been widely circulating in the market in Indonesia, but the existing national standards have not regulated the diversification of the coconut milk product. The aim of this study is to understand the characteristics of coconut milk products circulating in the market and analyze it in order to develop the concept RSNI for coconut milk products. The research method used in this study was to examine the results of the analysis of the quality parameters of coconut milk products and compare them with SNI 01-3816-1995 liquid coconut milk and codex stand 240-2003. The quality parameters analyzed were $\mathrm{pH}$, water content, total solids, fat and free fatty acids The results showed that light coconut milk, coconut milk, coconut cream, coconut cream concentrate, and coconut cream powder had $\mathrm{pH}$ range of $4.70-5.51$, water content of $2.41 \%$ for coconut cream powder, total solids of 14.07 $36.88 \%$, fat of $10.50-37.03 \%$, ffa of 0.21 to $0.37 \%$. Based on the results of the analysis of coconut milk product quality parameters and compared with SNI 01-3816-1995 liquid coconut milk and codex stand 240-2003, the concept of RSNI for coconut milk products are minimal $\mathrm{pH}$ of 5,9, maximum water content of $5 \%$ is only required for coconut cream concentrate, total solids for light coconut milk, coconut milk, coconut cream, coconut cream concentrate of 6.6-12.6\%; 12.7-25.3\%; 25.4-37.3\%; min. 37.4\%, but it is not determined for coconut cream powder, fat for light coconut milk, coconut milk, coconut cream, coconut cream concentrate and coconut cream concentrate of 5.0\%; $10.0 \%$; $20.0 \%$; 29.0\%; min. 30\%. ffa maximum for light coconut milk, coconut milk, coconut cream, and coconut cream concentrate of $0.3 \%$, and maximum for coconut cream concentrate of. $0.2 \%$.
\end{abstract}

Keywords: light coconut milk, coconut milk, coconut cream, coconut cream concentrate, coconut cream powder 


\section{PENDAHULUAN}

Tanaman kelapa (Cocos nucifera) merupakan salah satu tanaman industri yang potensial dan memiliki peranan penting baik dari segi nutrisi maupun segi ekonomi di Indonesia (Efendi, 2011). Banyaknya tanaman kelapa di Indonesia, dimanfaatkan masyarakat salah satunya yaitu menggunakan tanaman kelapa sebagai bahan baku pembuatan santan. Umumnya santan diperoleh dengan mengekstrak buah kelapa yang telah diparut dengan atau tanpa penambahan air sehingga menghasilkan cairan berwarna putih (Wulandari, 2017). Santan kelapa dikategorikan sebagai emulsi minyak dalam air (Cahya \& Susanto, 2014). Santan merupakan bahan makanan yang cepat rusak dan berbau tengik dalam beberapa jam (Palungkun, 2005), hal ini dikarenakan santan mempunyai kandungan air, lemak dan protein yang cukup tinggi (Srihari, et al., 2010).

Santan kelapa merupakan bahan pangan yang digunakan oleh hampir semua rumah tangga dan beberapa industri pangan. Kegunaan santan untuk berbagai kebutuhan dalam bidang pangan makin bertambah seiring dengan bertambahnya jumlah penduduk di Indonesia. Pemanfaatan santan pada umumnya adalah untuk bahan campuran masak dan pembuatan kue (Sukasih dkk., 2009).

Dalam masakan Indonesia, dikenal santan kental dan santan encer yang dibedakan berdasarkan kandungan airnya. Santan kental biasanya digunakan untuk masakan Padang seperti rendang misalnya, atau untuk kue-kue dan dessert. Sedangkan santan encer biasanya untuk sayur berkuah seperti sayur lodeh dan soto.

Perubahan trend dalam mengonsumsi santan kelapa saat ini terjadi karena perubahan pola pikir masyarakat. Mengonsumsi santan kelapa yang dibuat langsung dari buah kelapa sekarang ini dirasakan kurang efisien, karena pemerasan santan kelapa dengan cara tradisional atau dengan tangan memerlukan banyak waktu dan tenaga. Santan kelapa yang dihasilkan pun memiliki jangka waktu penyimpanan yang singkat atau mudah rusak. Hal ini yang mendasari produk santan kelapa kemasan menjadi pilihan yang tepat (Tunjungsari, Haryono \& Lestari, 2015).

Perkembangan teknologi yang semakin pesat menyebabkan kecenderungan masyarakat mencari sesuatu bahan yang bersifat praktis, mudah penyediaan dan penggunaannya, serta mempunyai daya simpan yang lama. Oleh karena itu, telah dilakukan pembuatan santan dalam bentuk siap pakai, antara lain dibuat menjadi santan instan (Anggrahini, 1999). Di pasaran, tersedia santan instan atau siap saji dalam kemasan (kaleng, tetra pak), santan beku serta santan bubuk. Santan bubuk merupakan produk instan yang langsung digunakan atau dilarutkan dengan air sesuai dengan kebutuhan (Prasetio, 2014).

Santan instan mempunyai masa simpan atau kadaluarsa lebih kurang selama 1 tahun. Penggunaannya relatif mudah karena tinggal ditambahkan air panas (hangat) serta kualitasnya dapat diterima konsumen, walaupun tidak sebaik kualitas santan yang dipersiapkan dalam rumah tangga dari kelapa segar (Soekopitojo, 2010).

Saat ini santan instan sudah sangat banyak beredar di pasaran di Indonesia, namun standar nasional yang ada belum mengatur diversifikasi produk santan yang beredar di pasaran. Oleh karena itu, untuk mendukung perkembangan dan diversifikasi produk santan yang beredar di pasaran, perlu disusun konsep RSNI Produk santan. Parameter yang dijadikan syarat mutu adalah $\mathrm{pH}$, kadar air, padatan total, lemak dan asam lemak bebas. Tujuan dari penelitian ini adalah untuk mengetahui karakteristik produk santan yang beredar di pasar dan menetapkan konsep SNI Produk santan.

\section{TINJAUAN PUSTAKA}

\subsection{Santan kelapa}

Sebagian produksi kelapa dikonsumsi dalam bentuk segar, terutama dalam bentuk santan. Santan merupakan cairan berwarna putih yang diekstrak dari daging kelapa parut dengan cara pengepresan mekanis, dengan atau tanpa penambahan sejumlah air (Balasubramaniam dan Sihotang, 1979). Santan kelapa mempunyai kadar air $86,41 \%$, kadar lemak $10,22 \%$, kadar protein $1,96 \%$ dan kadar karbohidrat $1,08 \%$ yang dikategorikan sebagai emulsi minyak dalam air (Djatmiko, 1983). Lemak pada santan kelapa merupakan lemak dengan kelompok asam lemak jenuh rantai medium (medium chain saturated fatty acids), yaitu asam laurat (C12:0) yang merupakan asam lemak utama dalam lemak kelapa serta asam kaprat (C10:0), asam lemak lain dalam lemak kelapa (Raghavendra dan Raghavarao, 2010).

Santan distabilisasi secara alamiah oleh protein (globulin dan albumin) dan fosfolipida (Tangsuphoom \& Coupland 2009). Dalam industri pangan, peran santan sangat penting baik sebagai 
sumber gizi, penambahan aroma, cita rasa, flavour dan perbaikan tekstur bahan pangan hasil olahan.

Santan merupakan emulsi minyak dalam air dengan ukuran partikel rata-rata sebesar $0,001 \mathrm{~mm}$ (Rosario dan Punzalan, 1977), sedangkan menurut Hegenmaier (1980), diameter globula lemak santan berukuran antara 0,01 - 0,02 mm dan berwarna putih susu. Seperti halnya dengan semua makroemulsi, emulsi santan relatif tidak stabil karena ukuran partikelnya relatif besar (lebih dari 1 mikron). Santan yang didiamkan beberapa saat (510 jam) akan memisah menjadi dua fase, yaitu fase kaya air (skim) pada bagian bawah dan fase kaya minyak (krim) pada bagian atas (Soekopitojo, 2010).

Santan segar mudah mengalami perubahan bila tidak diawetkan. Oleh karena itu, saat ini telah dikembangkan pengolahannya menjadi santan pasta dan santan konsentrat yang berdaya simpan lebih lama. Balasubramaniam (1976) menyatakan bahwa galaktomanan, fosfolipida dan protein dapat berfungsi sebagai emulsifier (pemantap emulsi) pada santan. Sedangkan fosfolipida di samping sebagai emulsifier, ternyata dapat menyebabkan perubahan warna menjadi putih kecoklatan akibat oksidasi asam lemak tak jenuh. Santan pasta atau krim kelapa adalah produk yang siap untuk dicampur pada pengolahan makanan-makanan tertentu. Bagi masyarakat perkotaan menggunakan krim kelapa merupakan cara yang sangat praktis.

\subsection{Emulsi santan}

Emulsi adalah suatu dispersi atau suspensi suatu cairan dalam cairan yang lain, dimana molekul-molekul kedua cairan tersebut tidak saling terbaur tetapi saling antagonistik (Winarno, 1992). Fase yang terdispersi disebut fase diskontinu atau globula-globula sedangkan cairan pendispersi yang mengelilingi globula-globula disebut fase kontinu atau fase eksternal (Tranggono, dkk., 1989).

Ada dua macam emulsi yaitu minyak dalam air (M/A) dan emulsi air dalam minyak (A/M). Emulsi $(\mathrm{M} / \mathrm{A})$ terbentuk bila minyak merupakan fase yang terdispersi dan air menjadi fase pendispersi, sedangkan emulsi (A/M) adalah sebaliknya. Faktor yang berpengaruh terhadap kedua tipe tersebut adalah tipe emulsifier yang digunakan, proporsi kedua fase dan pembuatan emulsi (Brennan, 1976). Santan adalah contoh emulsi minyak dalam air (Ranken and Kill, 1993).

Santan memiliki sistem emulsi minyak dalam air yang distabilkan oleh protein yang terabsorbsi pada lapisan antara minyak dan air. Protein bersama lemak membentuk senyawa lipoprotein yang menjadi lapisan pelindung pada butiran- butiran emulsi sehingga butiran-butiran emulsi tidak saling bercampur dan dapat terdispersi dengan baik. Lapisan pelindung dari lipoprotein akan menyebabkan emulsi minyak dalam air menjadi stabil (Chen and Dickinson, 1998). Santan kelapa secara alami mengandung protein yang berfungsi sebagai emulsifier alami (Narataruksa et al., 2010). Tetapi protein yang dikandung oleh santan amat sedikit jika dibandingkan minyak yang harus ditutupinya, oleh karena itu sistem emulsi santan sulit menjadi stabil. kekurangan protein santan dapat ditambahkan bahan lain sehingga emulsi lebih stabil (Djatmiko,1980).

\subsection{Santan bubuk}

Santan bubuk dibuat dari santan yang sudah diuapkan dan dikeringkan dengan suhu tinggi dengan alat yang disebut dengan spray dryer, sehingga dihasilkan bubuk yang mudah larut jika terkena air. Spray dryer mengeringkan setiap molekul air yang disemprotkan dan dipaparkan dengan udara kering dan panas, sehingga molekul air terbawa oleh udara dan padatan santan berupa bubuk jatuh ke dasar spray dryer. Santan bubuk merupakan olahan santan yang kadar airnya rendah karena adanya proses pengeringan dalam pembuatannya, sehingga santan bubuk umur simpannya lebih panjang bila dibandingkan dengan santan yang berbentuk cair. Sebelum digunakan bubuk santan dilarutkan dengan air hingga mendapatkan kekentalan yang diinginkan.

Sifatnya mudah larut dalam air hangat. Umumnya, santan bubuk dibungkus dalam kemasan alumunium. Santan bubuk memiliki kelebihan yang lebih tahan lama jika dibandingkan dengan santan cair dikarenakan apabila tidak habis sekali pakai maka dapat disimpan rapat dan digunakan kembali (Kusumah, 2017).

\section{METODE PENELITIAN}

\subsection{Bahan}

Bahan yang digunakan adalah santan encer, santan, santan krim, santan konsentrat dan santan bubuk masing-masing berjumlah 5 sampel. Bahanbahan analisis seperti amonium hidroksida $\left(\mathrm{NH}_{4} \mathrm{OH}\right)$ pekat, indikator fenolftalein $0,5 \%$, etil alkohol $95 \%$, etil eter, petroleum eter. etanol 95\%, kalium hidroksida $(\mathrm{KOH}$. Alat-alat analisis seperti neraca analitik dengan ketelitian $0,1 \mathrm{mg}$, oven, desikator, pemanas listrik, penangas air, cawan, labu ektraksi (labu lemak Mojonnier), pipet volumetric $25 \mathrm{~mL}$, buret $10 \mathrm{~mL}$, erlenmeyer $250 \mathrm{~mL}$. 


\subsection{Metode Analisis}

Penelitian ini dilakukan pada bulan Agustus November 2019. Pengujian mutu dilakukan di Laboratorium Pengujian Balai Besar Industri Agro. Parameter mutu yang dianalisis adalah $\mathrm{pH}$, kadar air, total padatan, lemak dan asam lemak bebas. Metode pH mengacu pada SNI ISO 1842, Produk buah dan sayur - Penentuan $\mathrm{pH}$. Kadar air mengacu ISO 5537, Dried milk - Determination of moisture content. Padatan total mengacu ke ISO 6731, Milk, Cream and Evaporated Milk Determination of Total Solid Content (Reference method). Lemak sesuai AOAC Official Method 932.06 Fat in Milk Powder. Asam lemak bebas mengikuti metode AOCS Official Method Ca 5a-40, Free Fatty Acids.

\section{HASIL DAN PEMBAHASAN}

Parameter mutu yang dianalisis untuk sampel produk santan adalah $\mathrm{pH}$, kadar air, padatan total, lemak dan asam lemak bebas. Hasil analisis akan dibandingkan dengan konsep RSNI Produk Santan, SNI 01-3816-1995 Santan cair dan Codex Stan 240-2003 Standard for Aqueous Coconut Products Coconut Milk and Coconut Cream

\section{$4.1 \quad \mathrm{pH}$}

Nilai pH santan encer, santan, santan krim, santan konsentrat dan santan bubuk dapat dilihat pada Tabel 1 yaitu $4,7 \pm 0,38 ; 4,86 \pm 0,38 ; 5,45 \pm 0,71$; $5,51 \pm 0,65 ; 5,29 \pm 0,42$. Data ini masih di bawah syarat mutu pH pada Codex Stan 240-2003 yaitu min. 5,9. Namun konsep RSNI Produk santan mengusulkan mengikuti Codex sebagai standar internasional yaitu min. 5,9 (Tabel 2).

Nilai pH pada sampel santan kemasan yang beredar di pasaran cenderung dibawah syarat mutu $\mathrm{pH}$ pada Codex stan. Rendahnya $\mathrm{pH}$ tersebut dapat diakibatkan oleh aktivitas mikroorganisme yang tumbuh cepat pada lingkungan yang sesuai dimana mikroorganisme tersebut mengubah karbohidrat dan turunannya menjadi alkohol dan karbondioksida sehingga memicu produksi asam (Kailaku et al. 2012). Selain dipengaruhi oleh aktivitas mikroba dalam santan, nilai $\mathrm{pH}$ juga dipengaruhi oleh kandungan asam lemak bebas yang terdapat dalam santan.

Nilai pH berkaitan dengan nilai asam dan nilai basa produk. Semakin kecil nilai pH maka semakin asam produk, sebaliknya semakin tinggi nilai $\mathrm{pH}$ maka semakin basa produk. Santan bermutu baik memiliki nilai $\mathrm{pH}$ netral. Jika nilai $\mathrm{pH}$ santan rendah, dapat menjadi indikasi adanya kontaminasi mikroba.

Tabel 1 Hasil uji analisa santan encer, santan, santan krim, santan konsentrat, dan santan bubuk

\begin{tabular}{|c|c|c|c|c|c|c|}
\hline No & Parameter & Santan encer & Santan & Santan krim & $\begin{array}{c}\text { Santan } \\
\text { konsentrat }\end{array}$ & $\begin{array}{c}\text { Santan } \\
\text { bubuk }\end{array}$ \\
\hline 1. & $\mathrm{pH}$ & $4,70 \pm 0,38$ & $4,86 \pm 0,38$ & $5,45 \pm 0,71$ & $5,51 \pm 0,65$ & $5,29 \pm 0,42$ \\
\hline 2. & Kadar air (\%) & & $\mathrm{TL}$ & & & $2,41 \pm 0,32$ \\
\hline 3. & Padatan total (\%) & $14,07 \pm 1,17$ & $24,33 \pm 2,50$ & $32,05 \pm 2,43$ & $36,88 \pm 1,56$ & TD \\
\hline 4. & Lemak (\%) & $10,50 \pm 1,23$ & $18,03 \pm 1,80$ & $23,20 \pm 1,29$ & $25,58 \pm 0,57$ & $37,03 \pm 8,36$ \\
\hline 5. & Asam lemak bebas (\%) & $0,33 \pm 0,04$ & $0,36 \pm 0,05$ & $0,37 \pm 0,07$ & $0,36 \pm 0,10$ & $0,21 \pm 0,10$ \\
\hline
\end{tabular}

Keterangan: Rerata \pm standar deviasi

$$
\text { TD = tidak dipersyaratkan }
$$

Tabel 2 Konsep RSNI Produk santan, SNI 01-3816-1995 santan cair dan codex stan 240-2003

\begin{tabular}{|c|c|c|c|c|c|c|c|c|c|c|c|}
\hline \multirow[t]{2}{*}{ No } & \multirow[t]{2}{*}{ Parameter } & \multicolumn{5}{|c|}{ Konsep RSNI Produk santan } & \multirow{2}{*}{$\begin{array}{l}\text { SNI 01- } \\
\text { 3816-1995 } \\
\text { Santan } \\
\text { cair }\end{array}$} & \multicolumn{4}{|c|}{ Codex stan $240-2003$} \\
\hline & & $\begin{array}{l}\text { Santan } \\
\text { encer }\end{array}$ & Santan & $\begin{array}{l}\text { Santan } \\
\text { krim }\end{array}$ & $\begin{array}{c}\text { Santan } \\
\text { konsentrat }\end{array}$ & $\begin{array}{l}\text { Santan } \\
\text { bubuk }\end{array}$ & & $\begin{array}{l}\text { Light } \\
\text { coco } \\
\text { nut } \\
\text { milk }\end{array}$ & $\begin{array}{l}\text { Coco } \\
\text { nut } \\
\text { milk }\end{array}$ & $\begin{array}{l}\text { Coco } \\
\text { nut } \\
\text { cream }\end{array}$ & $\begin{array}{l}\text { Coco } \\
\text { nut } \\
\text { cream } \\
\text { conce } \\
\text { ntrate }\end{array}$ \\
\hline 1. & $\mathrm{pH}$ & & & Min 5, & & & - & 5,9 & 5,9 & 5,9 & 5,9 \\
\hline 2. & $\begin{array}{l}\text { Kadar air } \\
(\%)\end{array}$ & & & TD & & $\begin{array}{c}\text { Maks. } \\
5\end{array}$ & Maks. 50 & 93,4 & 87,3 & 74,6 & 62,6 \\
\hline 3. & $\begin{array}{l}\text { Padatan } \\
\text { total (\%) }\end{array}$ & $\begin{array}{l}6,6- \\
12,6\end{array}$ & $\begin{array}{l}12,7- \\
25,3\end{array}$ & $\begin{array}{c}25,4- \\
37,3\end{array}$ & Min. 37,4 & TD & - & $\begin{array}{l}6,6- \\
12,6\end{array}$ & $\begin{array}{l}12,7- \\
25,3\end{array}$ & $\begin{array}{c}25,4- \\
37,3\end{array}$ & $\begin{array}{l}\text { Min. } \\
37,4\end{array}$ \\
\hline 4. & $\begin{array}{l}\text { Lemak } \\
(\%)\end{array}$ & 5,0 & 10,0 & 20,0 & 29,0 & Min. 30 & Min. 30 & 5,0 & 10,0 & 20,0 & 29,0 \\
\hline
\end{tabular}




\begin{tabular}{|c|c|c|c|c|c|c|c|c|c|c|c|}
\hline \multirow[t]{2}{*}{ No } & \multirow[t]{2}{*}{ Parameter } & \multicolumn{5}{|c|}{ Konsep RSNI Produk santan } & \multirow{2}{*}{$\begin{array}{l}\text { SNI 01- } \\
\text { 3816-1995 } \\
\text { Santan } \\
\text { cair }\end{array}$} & \multicolumn{4}{|c|}{ Codex stan 240-2003 } \\
\hline & & $\begin{array}{l}\text { Santan } \\
\text { encer }\end{array}$ & Santan & $\begin{array}{l}\text { Santan } \\
\text { krim }\end{array}$ & $\begin{array}{c}\text { Santan } \\
\text { konsentrat }\end{array}$ & $\begin{array}{l}\text { Santan } \\
\text { bubuk }\end{array}$ & & $\begin{array}{l}\text { Light } \\
\text { coco } \\
\text { nut } \\
\text { milk }\end{array}$ & $\begin{array}{l}\text { Coco } \\
\text { nut } \\
\text { milk }\end{array}$ & $\begin{array}{l}\text { Coco } \\
\text { nut } \\
\text { cream }\end{array}$ & $\begin{array}{l}\text { Coco } \\
\text { nut } \\
\text { cream } \\
\text { conce } \\
\text { ntrate }\end{array}$ \\
\hline 5. & $\begin{array}{l}\text { Asam } \\
\text { lemak } \\
\text { bebas (\%) }\end{array}$ & & & Ks. 0,3 & & $\begin{array}{c}\text { Maks. } \\
0,2\end{array}$ & - & - & - & - & - \\
\hline
\end{tabular}

Keterangan: $T D=$ tidak dipersyaratkan

\subsection{Kadar air}

Hasil analisa kadar air pada sampel santan bubuk yang beredar di pasar yaitu 2,41 $\pm 0,32$. Analisa kadar air dipersyaratkan hanya pada santan bubuk, karena kadar air merupakan salah satu penentu apakah suatu produk dalam bentuk bubuk tahan lama disimpan atau tidak. Selain itu, kadar air juga berpengaruh pada penampakan dan kecepatan larut bubuk dalam air (Srihari, et al., 2010). Kisaran hasil analisa kadar air pada sampel santan bubuk tersebut hampir sama dengan syarat kadar air dalam susu bubuk yaitu antara $2-4 \%$. Kadar air santan bubuk yang rendah akan membuat santan memiliki kestabilan fisik dan kimiawi yang baik bila disimpan dalam jangka waktu yang lama

Kadar air dalam santan menunjukkan jumlah air yang terdapat dalam santan. Kadar air merupakan salah satu penentu keawetan suatu produk. Hal tersebut terkait dengan ketersediaan air yang terdapat dalam produk untuk dapat digunakan oleh mikroorganisme. Kadar air santan kelapa bubuk yang rendah menjamin waktu simpan yang lebih panjang dibandingkan

dengan produk yang berkadar air tinggi.

Menurut Ketaren (1986) terdapatnya sejumlah air dalam minyak atau lemak dapat mengakibatkan terjadinya reaksi hidrolisis. yang menghasilkan asam lemak bebas (FFA). Asam lemak, dihasilkan melalui reaksi hidrolisis yang dapat disebabkan oleh sejumlah air, enzim ataupun aktivitas mikroorganisme. Semakin tinggi kadar air dalam lemak, kemungkinan besar kadar asam lemak juga tinggi.

\subsection{Padatan total}

Padatan total pada santan encer, santan, santan krim, dan santan konsentrat dapat dilihat pada Tabel 1 yaitu sebesar $14,07 \pm 1,17 \% ; 24,33 \pm$ $2,50 \% ; 32,05 \pm 2,43 \% ; 36,88 \pm 1,56 \%$, sedangkan untuk santan bubuk tidak dipersyaratkan. Data ini masuk ke syarat mutu padatan total pada Codex stan 240-2003 yaitu 6,6-12,6\%; 12,7-25,3\%; 25,437,3\%; Min. 37,4\%, sehingga untuk konsep RSNI produk santan padatan total yang ditentukan mengikuti standar padatan total pada Codex stan.

Selama pemanasan, kadar air dalam santan menguap sehingga menyebabkan padatan total menjadi meningkat. Selain itu menurut Anon (1984) dalam Prihatini (2008) komponen utama karbohidrat dalam santan adalah sukrosa dan pati. Pemanasan dapat menyebabkan terserapnya air ke dalam granula pati. Jumlah gugus hidroksil yang besar pada pati menyebabkan air yang pada awalnya berada di luar granula dan bebas bergerak terserap ke dalam granula pati dan tidak bergerak bebas lagi.

\subsection{Lemak}

Hasil analisis lemak santan encer, santan, santan krim, santan konsentrat dan santan bubuk sebesar 10,50 $\pm 1,23 \% ; 18,03 \pm 1,80 \% ; 23,20 \pm$ $1,29 \% ; 25,58 \pm 0,57 \% ; 37,03 \pm 8,36 \%$ dapat dilihat pada Tabel 1. Nilai lemak pada santan encer, santan dan santan krim lebih tinggi jika dibandingkan dengan syarat mutu lemak pada codex stan yaitu sebesar $5,0 \%, 10,0 \%$ dan $20,0 \%$. Sementara pada santan konsentrat, nilai lemak lebih rendah dibandingkan dengan syarat mutu pada codex stan yaitu sebesar $29,0 \%$. Namun pada konsep RSNI Produk santan mengusulkan lemak mengikuti standar mutu lemak pada codex stan.

Kadar lemak santan pada dasarnya dipengaruhi oleh daging buah kelapa itu sendiri. Semakin tua buah kelapa, semakin tinggi pula kadar lemak yang terkandung di dalam buah. Lemak merupakan salah satu komponen penting dalam santan. Lemak yang terdapat dalam santan akan mempengaruhi parameter mutu santan lainnya seperti bilangan peroksida dan asam lemak bebas. Lemak pada santan merupakan lemak jenuh, namun dengan rantai medium (Raghavendra dan Raghavarao, 2010). Lemak merupakan komponen santan yang membentuk emulsi. Kadar lemak yang tinggi menyebabkan jumlah globula lemak semakin banyak, sehingga akan membentuk 
system emulsi minyak dalam air yang stabil (Budianta, Harijono \& Murtini, 2000).

\subsection{Asam lemak bebas}

Hasil analisis asam lemak bebas santan encer, santan, santan krim, santan konsentrat dan santan bubuk sebesar 0,33 $\pm 0,04 \% ; 0,36 \pm 0,05$ $\% ; 0,37 \pm 0,07 \% ; 0,36 \pm 0,10 \% ; 0,21 \pm 0,10 \%$ dapat dilihat pada Tabel 1. Untuk konsep RSNI Produk santan mengusulkan kadar asam lemak bebas maks. 0,3\% untuk santan encer, santan, santan krim dan santan konsentrat. Sementara untuk santan bubuk ditetapkan sebesar 0,2\%. Hal ini mempertimbangkan bahwa dalam proses pembuatan santan yang menggunakan panas otomatis akan menaikkan kadar asam lemak bebas pada produk. Kenaikan asam lemak bebas disebabkan oleh adanya proses hidrolisis lemak yang kemudian terurai menjadi asam lemak dan gliserol (Sukasih et al., 2009).

Asam lemak bebas merupakan salah satu parameter mutu minyak dan lemak. Menurut Marina et al., (2008), asam lemak bebas merupakan hasil hidrolisis lemak yang akan menimbulkan bau tengik pada santan. Hidrolisis ini dipacu oleh lipase yang secara alamiah ada pada bagian jaringan yang mengandung minyak atau lemak (Song et al., 2005). Aktivitas lipase dipengaruhi oleh berbagai faktor antara lain adalah suhu.

\section{KESIMPULAN}

Produk santan yang terdiri dari santan encer, santan, santan krim, santan konsentrat dan santan bubuk mempunyai kisaran nilai $\mathrm{pH}$ sebesar 4,705,51 , kadar air santan bubuk 2,41\%, padatan total sebesar 14,07-36,88\%, kadar lemak sebesar 10,50-37,03\%, dan kadar asam lemak bebas 0,210,37\%. Sedangkan SNI 3816-1995 Santan cair hanya mempunyai syarat mutu kadar air maks. 50\% dan lemak min. 30\%. Syarat mutu pH santan encer, santan, santan krim santan kosentrat dan santan bubuk belum memenuhi Codex dengan syarat mutu pH min. 5,9, sementara untuk syarat mutu yang lain, yaitu kadar air maks. $5 \%$ hanya dipersyaratkan untuk santan bubuk, padatan total mengikuti standar Codex stan 240-2003 untuk santan encer, santan, santan krim dan santan konsentrat sebesar 6,6-12,6\%; 12,7-25,3\%; 25,4-37,3\%; min. 37,4\%, untuk santan bubuk tidak ditetapkan, kadar lemak untuk santan encer, santan, santan krim, santan konsentrat dan santan bubuk berturut-turut sebesar 5,0\%; 10,0\%; 20,0\%; 29,0\%; min. 30\%. Kadar asam lemak bebas untuk santan encer, santan, santan krim dan santan konsentrat maks. 0,3\%, dan maks. $0,2 \%$ untuk santan bubuk.

\section{UCAPAN TERIMA KASIH}

Penulis mengucapkan terimakasih kepada Sub Direktorat Industri Pengolahan Hasil Perkebunan, Direktorat Industri Makanan Hasil Laut dan Perikanan, Direktorat Jenderal Industri Agro, Kementerian Perindustrian yang telah mendanai analisis produk santan ini. Tidak lupa penulis mengucapkan terima kasih kepada lbu Ir. Nurwidiani dan Ibu Ning Ima Arie Wardayanie, S.TP, MPharm.Sc atas bimbingannya dalam penyusunan SNI Produk santan ini.

\section{DAFTAR PUSTAKA}

Anggrahini, S. (1999). Pengaruh penambahan CMC dan kuning telur terhadap karakteristik santan instan. Prosiding seminar nasional pangan. PAU UGM. Yogyakarta.

Anon. (1984). Coconut cream, raw. NDB no. 12115, Nutrition Data Base. University of Minnesota, USA.

AOAC Official Method 932.06, Fat in Milk Powder. Final Action.

AOCS. (2016). AOCS Official Method Ca 5a-40, Free fatty acids in Official Methods and Recommended Practices of the AOCS 7th Edition, Urbana, Illinois.

Balasubramaniam, K. (1976).Polysaccharides of the kernel of maturity and mature coconuts. Journal of Food Science. 41: 1.370-1.371.

Balasubramaniam, K. \& K. Sihotang. (1979). Studies of coconut protein and its enzyme activities. Journal of Food Science. 44(1): 62-65.

Brennan, J. G., Butters, J. R., Cowell, N. D., \& Lilly, A. E. V. (1976). Food engineering operations (No. Ed. 2). Applied Science Publishers Ltd.

Budianta, T. D. W., \& Harijono, M. (2012). Pengaruh Penambahan Kuning Telur Dan Maltodekstrin Terhadap Kemampuan Pelarutan Kembali Dan Sifat Organoleptik Santan Bubuk Kelapa (Cocos nucifera L.). Jurnal Teknologi Pangan dan Gizi, 1(2).

Cahya, F. \& Susanto, W.H. (2014). Pengaruh pohon pasca sadap dan kematangan buah kelapa terhadap sifat fisik, kimia, organoleptik pasta santan. Jurnal Pangan dan Agroindustri. 2(4): 249-258.

Chen, J., \& Dickinson, E. (1998). Viscoelastic properties of heat-set whey protein emulsion gels. Journal of Texture Studies, 29(3), 285- 
304.CODEX. (2003). Codex standard for aqueous coconut products. Journal of Codex Stan. 240:1-4.

Dewan Standar Nasional Indonesia. SNI-1-38161995. (1995). Santan cair.

Djatmiko, B. (1980). Pengolahan kelapa. Jurusan Teknologi Industri. Fakultas Teknologi Pangan IPB. Bogor.

Djatmiko, B. (1983). Pengolahan kelapa I. Jurusan Teknologi Industri FATETA, IPB. Bogor.

Efendi, R. (2011). Kombinasi pemberian natrium bisulfit (NaHSO3) dan pengurangan santan dalam pembuatan kelapa parut kering. SAGU. 10(1), 35-41.

Hegenmaier, R. (1980). Coconut aqueous processing. University of San Carlos. Cebu City. Philipina.

ISO 5537:2004, Dried Milk - Determination of moisture content.

ISO 6731:2010, Milk, cream and evaporated milk Determination of total solid content (Reference method).

Kailaku, S.I., T. Hidayat \& D.A Setiabudy. (2012). Pengaruh kondisi homogenisasi terhadap karakteristik fisik dan mutu santan selama penyimpanan. Jurnal Litri. 18(1): 31-39.

Ketaren S. (1986). Pengantar teknologi minyak dan lemak pangan. Jakarta: UI-Press.

Kusumah, G.R.B. (2017). Pengaruh formula dan perbandingan bumbu serbuk dengan santan serbuk terhadap karakteristik bumbu gulai serbuk dengan metode foam-mat drying. Program Studi Teknologi Pangan. Fakultas Teknik. Universitas Pasundan. Bandung.

Marina, A.M., Y.B.C. Man, S.A.H. Nazimah, \& Amin. (2008). Monitoring the Adulteration of Virgin Coconut Oil by Selected Vegetable Oils Using Differential Scanning Calorimetry. Journal of Food Lipids 16: 50-61.

Narataruksa, P., Pichitvittayakarn, W., Heggs, P. J., \& Tia, S. (2010). Fouling behavior of coconut milk at pasteurization temperatures. Applied thermal engineering, 30(11-12), 1387-1395.

Palungkun, R. (2005). Aneka Produk Olahan Kelapa. Penebar Swadaya. Jakarta.

Prasetio, A. (2014). Pengaruh santan segar dan santan instan terhadap mutu organoleptik dan fisik rendang daging, Jurusan Teknologi Hasil Pertanian Fakultas Teknologi Pertanian Universitas Jember,
Prihatini, R.I. (2008). Analisa kecukupan panas pada proses pasteurisasi santan. Fakultas Teknologi Pertanian IPB. Bogor.

Raghavendra, S. N., \& Raghavarao, K. S. M. S. (2010). Effect of different treatments for the destabilization of coconut milk emulsion. Journal of food engineering, 97(3), 341-347.

Ranken \& Kill. (1993). Food Industry's Manual. Kapitan Szabo Pub. USA.

Del Rosario, R. R., \& Punzalan, G. C. (1977). Quality control of coconut milk processing: emulsion stability studies. Philippine journal of coconut studies.

Soekopitojo, Soenar. (2010). Fungsionalitas santan. http://Pasta santan/index1.htm. Diakses tanggal 8 September 2020.

Song, J. K., Han, J. J., \& Rhee, J. S. (2005). Phospholipases: occurrence and production in microorganisms, assay for high-throughput screening, and gene discovery from natural and man-made diversity. Journal of the American Oil Chemists' Society, 82(10), 691705.

Srihari, E., FSri Lingganingrum, F., Hervita, R., \& Wijaya S, H. (2010). Pengaruh penambahan maltodekstrin pada pembuatan santan kelapa bubuk.

Sukasih, E., Prabawati, S., Hidayat, T., \& Rahayuningsih, M. (2009). Optimasi kecukupan panas pada pasteurisasi santan dan pengaruhnya terhadap mutu santan yang dihasilkan. J Pascapanen, 6(1), 34-42.

Tangsuphoom, N., \& Coupland, J. N. (2009). Effect of surface-active stabilizers on the surface properties of coconut milk emulsions. Food Hydrocolloids, 23(7), 1801-1809.

Tranggono. (1989). Bahan Tambahan Pangan. PAU Pangan dan Gizi. UGM. Yogyakarta

Tunjungsari, M., Haryono, D., \& Lestari, D. A. H. (2015). Kepuasan dan loyalitas konsumen ibu rumah tangga dalam mengonsumsi santan Sun Kara di Kota Bandar Lampung. Jurnal IImu-IImu Agribisnis, 3(3).

Winarno, F.G. (2002). Kimia pangan dan gizi. PT.Gramedia Pustaka Utama. Jakarta.

Wulandari, N., Lestari, I., \& Alfiani, N. (2017). Peningkatan Umur Simpan Produk Santan Kelapa dengan Aplikasi Bahan Tambahan Pangan dan Teknik Pasteurisasi. Jurnal Mutu Pangan (Indonesian Journal of Food Quality), 4(1), 30-37. 
Prosiding PPIS 2020 - Tangerang Selatan, 5 November 2020: Hal 231-238 